\title{
Customers' Perception regarding Assurance of Bancassurance Channel
}

\author{
Mousumi CHOUDHURY, ${ }^{1}$ Ranjit SINGH ${ }^{2}$ \\ ${ }^{1}$ Department of Business Administration, Research Scholar, Assam University, Silchar, \\ Assam, India, e-mail: choudhurymousumi@yahoo.co.in \\ ${ }^{2}$ Department of Business Administration, Assistant Professor, Assam University, Silchar, \\ Assam, India, e-mail: look_for_ranjit@yahoo.in
}

\begin{abstract}
Bancassurance has evolved as a strong distribution channel in India. Bancassurance means that the insurance company and the bank come together to offer insurance products from the counter of the banks to the bank's customer. The present study attempts to analyse customers' perception regarding assurance of bancassurance channel in providing insurance-related services. The study also tries to find out the impact of various demographic variables on customers' perception regarding assurance of bancassurance channel. The study finds that customers consider bancassurance channel having high assurance in providing insurance services. It is also found in the study that there is no significant association between the demographic variables considered in the study and customers' perception regarding assurance of bancassurance channel.
\end{abstract}

Keywords: bank, insurance, State Bank of India

JEL Classifications: M21, M310, M370

\section{Introduction}

In today's competitive marketplace, customers' perceptions are becoming important for gaining sustainable competitive advantage. Customer's perception has become an important tool for evaluating marketing strategies. People have begun to believe that the perception of customers towards the company's image and its products affects the purchasing decisions of customers.

In the case of banks, customers' perception is formed through customers' assessment of the quality of services provided by a bank and their satisfaction level with the overall service of the bank (Zeithaml and Bitner, 2003). Customers' perception with respect to the bank means the customers' overall picture of the bank, including the bank's image, expectations, external influences, service quality, etc. All interactions that occur between the customers and the bank will 
ultimately affect the customers' view and image of the bank. All that customers see, hear, and experience is linked together and forms their overall perception towards the bank (Aspfors, 2010).

The banking industry has undergone rapid changes, followed by a series of fundamental developments due to liberalization and financial deregulation. These result in increasing competition among financial institutions. In this competitive scenario, banks are devising new products and formulating new business models to create and sustain competitive advantages over their competitors. One such model is 'bancassurance' (Malik, 2014).

Bancassurance is a business model that refers to the selling of insurance policies through a bank's established distribution channels (Aggrawal, 2004). It is the concept of selling insurance plans by a bank along with a complete range of banking and investment products and services (Venugopal, 2011).

In a bancassurance model, banks do not only face competition from other banks. Rather they face competition from insurance companies and individual insurance agents working with agency channels. These raise a deep concern among banks as to how they can influence their customers in order to entice and retain their customers. In such competitive marketplace, customer satisfaction is seen as a key differentiator and a key element of business strategy. Providing assurance in banking service has significant impact on customer satisfaction (Munusamy et. al, 2010; Nautiyal, 2014; Selvakumar, 2015). It is well established that satisfied customers are key to long-term business success (Kristensen et al., 1992; Zeithami et al., 1996; McColl-Kennedy and Scheider, 2000).

Assurance is a means of being safe. Assurance is developed by the level of knowledge and courtesy displayed by the employees in rendering the services and their ability to instil trust and confidence in customers (Blery et al., 2009). It includes all the factors, such as communication, courtesy, and facilities, which make customers confident and sure that the service commitment is fulfilled (Nautiyal, 2014). By displaying a trustworthy behaviour on the part of the employees of financial institutions, the satisfaction level of customers can be significantly enhanced (Khan and Fasih, 2014). This also positively influences the repurchase intention of customers (Ndubisi, 2006; Ndubisi and Wah, 2005).

Reflecting on all these points, the present study attempts to investigate customers' perception regarding assurance of bancassurance channel. The influence of demographic variables on customers' perception regarding assurance is also studied. 


\section{Measuring Customers' Perception of Assurance regarding Bancassurance Channel}

Various studies are conducted about customers' perception regarding assurance provided by banks in their services. In their study, Munusamy et al. (2010) and Nautiyal (2014) found that assurance has a positive relationship with customer satisfaction. Kaura (2013) in his study concluded that employee behaviour has a positive impact on the satisfaction of private sector bank customers in India. Siddiqui (2011), in a study conducted in Bangladesh, concluded that there was a medium to high correlation between customer satisfaction and the five dimensions of service quality: tangibility, responsiveness, reliability, assurance, and empathy.

Culiberg \& Rojšek (2010) determined that assurance and empathy were the most critical factors in determining satisfaction amongst bank customers in Slovenia. Assurance has significant and positive association with customer satisfaction and customer loyalty (Khan and Fasih, 2014). Banks must consider various antecedents (tangibles, reliability, assurance, and empathy) of service quality in order to have delighted customers (Sharp \& Sharp, 1997) and to enhance the bank's performance and profitability (Hackl et al., 2000; Andereson et al., 1994; Lewis, 1993). Customer loyalty is more strongly impacted by assurance than by any other dimension of service quality (Bitner, 1990). Sulieman (2013) found that assurance has an impact on the level of customer satisfaction. Among the service quality determinants, reliability, assurance, and empathy have always played a pivotal role in satisfying customers (Selvakumar, 2015). There is a significant relationship between assurance and customer loyalty (Kheng et al., 2010; Lymperopoulos et al., 2006; Ndubisi, 2006; Lymperopoulos, Chaniotakis, and Soureli, 2006; Auka et al., 2013). Assurance was found to be a significant prediction of customer satisfaction (Ndubisi, 2006). Tangibility, responsibility, reliability, and assurance were more significant in contributing to customer satisfaction, while empathy was the least significant (Lau et al., 2013). Mengi (2009) found that responsiveness and assurance are more important. Lo, Osman, Ramayah, and Rahim (2010) found that empathy and assurance had the highest influence on customer satisfaction in the Malaysian retail banking industry. Assurance is another factor emphasized by customers in Hong Kong. The degree of trust and confidence that customers feel about the banking services greatly depends on the service quality provided by the employees of banks (Lau et al., 2013). The study found assurance (knowledge and courtesy of employees and their ability to inspire trust and confidence) to be a significant driver of customer loyalty (Koduah and Farley, 2016). Reliability, responsiveness, empathy, and assurance influence users' evaluation of service quality of banking services (Saghier and 
Nathan, 2013). Studies by Choudhury and Singh (2015c) and Choudhury et al. (2016) found that customers have positive experiences of buying insurance from bancassurance channel. Dharmalingam et al. (2012) concluded that customers' highest expectations are towards the security and accessibility dimensions and their lowest expectations are towards the responsiveness dimension. Choudhury and Singh (2015a) studied the reliability and responsiveness of the bancassurance channel (Choudhury and Singh, 2015b). Javadi et al. (2012) stated that assurance and reliability seems to be the most important dimensions in private banks. Muyeed (2012) in his study aimed at evaluating the service quality in retail banking in the developing countries in general and in Bangladesh. The results indicate that customers' perception were highest regarding the promptness and accuracy in transactions, followed by the safety of customers' investments and keeping the confidentiality of accounts and transactions. Heryanto (2011) concluded that assurance shows the slightest shortfall when compared with customer expectation. Assurance has a significant contribution in boosting the satisfaction level of the bank customers of Pakistan (Malik et al., 2011). Customers are satisfied with the security aspects of SBI Coimbatore (Santhiyavalli, 2011).

In the case of life insurance services, the priority areas of service instrument with assurance are the best predictor - customers perceive assurance (with a relative weight of $36 \%$ ) as the most important dimension of overall expectations of service quality (Siddiqui and Sharma, 2010). Putting the customer first and exhibiting trust and integrity were found to be essential in selling insurances (Slattery, 1989). In their study, Singh and Kaur (2011) reveal that responsiveness, tangibles, services innovation, reliability and accessibility, assurance, pricing and other facilities, problem-solving capability, and convenient working hours are the main determinants of customer satisfaction in insurance industry as perceived by the customers. A complete peace of mind after getting insured from the particular company is considered to be the most important factor influencing customers' perception of the life insurance industry (Anjor et al., 2014). The four major factors which influence customer perception of service quality are responsiveness and assurance, convenience, tangibles, and empathy (Singh et al., 2014).

\section{Objectives of the Study}

The study has the following objectives:

i. To find out customers' perception regarding assurance of bancassurance channel.

ii. To study the influence of demographic variables on customers' perception of assurance of bancassurance channel. 


\section{Hypothesis}

The hypothesis considered for the study is as follows:

There is no significant association between the demographic profile and customers' perception of assurance of bancassurance channel.

\section{Research Methods}

The study is conducted using the following research methodology:

\subsection{Universe of the Study}

The universe of the study consists of all those customers of 37 branches of the State Bank of India, Guwahati, who have received life-insurance-related services through the different branches of the State Bank of India. The total number of such customers on $11^{\text {th }}$ March 2013 was 3,315.

\subsection{Sampling Unit and Sample Size}

Using random sampling at $95 \%$ confidence level and $5 \%$ confidence interval, a sample of 345 customers is obtained. The sampling unit is the customer of the bank who has previously bought a life insurance product from the bank.

\subsection{Data Collection}

The study is mainly based on primary data. The tool of "structured questionnaire" is used to collect the necessary information relevant for the study. For secondary data, official reports and records, journals, newspapers, and magazines are accessed.

\subsection{Development of the Questionnaire}

The questionnaire is developed for collecting primary data from the bank customers who have previously bought insurance policy from the bank. The questionnaire was designed to measure the perception of the customers regarding assurance of bancassurance channel. The variables considered to measure assurance dimension were converted into statements, and respondents were asked to give their opinion on those statements on a 5-point scale. There were five numbers of statements measuring customers' perception regarding assurance of bancassurance channel. Thus, the responses regarding these five numbers of 
statements were obtained on a 5-point scale ranging from 5 to 1 for each of the selected dimension, where 5 denotes very high level of assurance and 1 indicates very low level of assurance. Some of the questions were in reverse scaling to ensure accuracy of response.

\subsection{Tools for Data Analysis}

To investigate the perception of customers' towards bancassurance channel, statistical tools like mean, standard deviation, value of Cronbach's alpha, Cramer $\mathrm{V}$ test, and multiple linear regression analysis are used.

\section{Analysis and Findings}

Analysis and findings of the study are given under the following paragraphs:

\subsection{Reliability of the Questionnaire}

The reliability of the questionnaire is tested using Cronbach's Alpha. The result of the test is given in Table 1.

Table 1. Reliability Statistics

\begin{tabular}{ccc}
\hline Cronbach's Alpha & $\begin{array}{c}\text { Cronbach's Alpha based } \\
\text { on standardized items }\end{array}$ & N of items \\
\hline .772 & .805 & 5 \\
\hline
\end{tabular}

The reliability of the scale was evaluated and the coefficient of Cronbach's Alpha was found to be 0.772 for 5 items (or statements) considered for the study. A high value of Cronbach's Alpha (0.772) is indicative of a high degree of reliability of the scale and it also shows that the items are highly correlated. A Cronbach's Alpha higher than 0.70 is considered to be a good measure of reliability of the scale (Nunnaly, 1978). 


\subsection{Measuring the Perception of Customers towards Assurance of Ban- cassurance Channel}

Table 2. Item statistics for measuring assurance of bancassurance channel

\begin{tabular}{lcc}
\hline Particulars & Mean & Standard deviation \\
\hline Feel free to talk about insurance problems & 3.97 & 0.496 \\
\hline Knowledge level of sales personnel & 3.76 & 0.623 \\
\hline Politeness of sales personnel & 3.72 & 0.642 \\
\hline Sympathetic approach & 3.62 & 0.738 \\
\hline $\begin{array}{l}\text { Giving financial advice other than on } \\
\text { insurance }\end{array}$ & 2.39 & 0.979 \\
\hline
\end{tabular}

Source: Compiled from the questionnaire

Table 2 shows that customers perceive that assurance provided by a bancassurance channel is relatively high with respect to factors such as "feel free to talk about insurance-related problems" and is relatively low regarding factors such as "giving financial advice other than on insurance".

Table 3. Scale statistics for assurance of bancassurance channel

\begin{tabular}{cccc}
\hline Mean & Variance & Standard deviation & N of items \\
\hline 17.45 & 6.661 & 2.581 & 5 \\
\hline & \multicolumn{3}{c}{ Source: Compiled from the questionnaire }
\end{tabular}

Exhibit 1. Interpretation table to interpret the assurance score of bancassurance channel

\begin{tabular}{cc}
\hline Perception score & Interpretation \\
\hline $5-9$ & Very low level of assurance \\
\hline $9-13$ & Low level of assurance \\
\hline $13-17$ & Moderate level of assurance \\
\hline $17-21$ & High level of assurance \\
\hline $21-25$ & Very high level of assurance \\
\hline
\end{tabular}

Table 3 shows that the mean score is 17.45. It falls in the category of high level of assurance as presented in Exhibit 1. Thus, it can be interpreted that customers of bancassurance perceive that banks provide a high degree of assurance regarding insurance-related services. This finding is in accordance with the findings of Vikas (2011) and Rajasekar and Kumari (2014). 


\subsection{Impact of the Demographic Profile on Customers' Perception regar- ding Assurance of Bancassurance Channel}

The impact of the demographic profile of customers on their perception of assurance of bancassurance is presented under the following paragraphs.

\subsubsection{Age of Customers and Customers' Perception regarding Assurance of Bancassurance Channel}

The relation between the age of customers and customers' perception of assurance of bancassurance channel is presented in Table 4.

Table 4. Age of customers and customers' perception of assurance

\begin{tabular}{|c|c|c|c|c|c|c|c|}
\hline & & \multicolumn{5}{|c|}{ Age } & \multirow[b]{2}{*}{ Total } \\
\hline & & $\begin{array}{c}\text { Less than } \\
25 \text { years }\end{array}$ & $\begin{array}{c}25 \text { years } \\
\text { to } 35 \\
\text { years }\end{array}$ & $\begin{array}{c}35 \text { years } \\
\text { to } 45 \\
\text { years }\end{array}$ & $\begin{array}{c}45 \text { years } \\
\text { to } 55 \\
\text { years }\end{array}$ & $\begin{array}{c}\text { More than } \\
55 \text { years }\end{array}$ & \\
\hline \multirow{2}{*}{$\begin{array}{l}\text { Low } \\
\text { assurance }\end{array}$} & Count & 0 & 1 & 1 & 2 & 0 & 4 \\
\hline & $\%$ of total & $.0 \%$ & $.3 \%$ & $.3 \%$ & $.6 \%$ & $.0 \%$ & $1.2 \%$ \\
\hline \multirow{2}{*}{$\begin{array}{l}\text { Moderate } \\
\text { assurance }\end{array}$} & Count & 1 & 5 & 25 & 58 & 17 & 106 \\
\hline & $\%$ of total & $.3 \%$ & $1.4 \%$ & $7.2 \%$ & $16.8 \%$ & $4.9 \%$ & $30.7 \%$ \\
\hline \multirow{2}{*}{$\begin{array}{l}\text { High } \\
\text { assurance }\end{array}$} & Count & 0 & 8 & 58 & 104 & 34 & 204 \\
\hline & $\%$ of total & $.0 \%$ & $2.3 \%$ & $16.8 \%$ & $30.1 \%$ & $9.9 \%$ & $59.1 \%$ \\
\hline \multirow{2}{*}{$\begin{array}{l}\text { Very high } \\
\text { assurance }\end{array}$} & Count & 0 & 3 & 9 & 15 & 4 & 31 \\
\hline & $\%$ of total & $.0 \%$ & $.9 \%$ & $2.6 \%$ & $4.3 \%$ & $1.2 \%$ & $9.0 \%$ \\
\hline \multirow{2}{*}{ Total } & Count & 1 & 17 & 93 & 179 & 55 & 345 \\
\hline & $\%$ of total & $.3 \%$ & $4.9 \%$ & $27.0 \%$ & $51.9 \%$ & $15.9 \%$ & $100.0 \%$ \\
\hline
\end{tabular}

There is no significant correlation between the age of customers and their perception regarding assurance of bancassurance. This is because the Approx. Significant value of Cramer's V test is 0.686 , which is more than 0.05 (5\% level of significance).

\subsubsection{Gender of Customers and Their Perception regarding Assurance of Bancassurance Channel}

The correlation between the gender of customers and their perception of assurance of bancassurance is outlined in Table 5 . 
Table 5: Gender of customers and their perception of assurance

\begin{tabular}{lcccc}
\hline & & \multicolumn{2}{c}{ Gender } & \\
\cline { 3 - 4 } & & Male & Female & Total \\
\hline Low & Count & 4 & 0 & 4 \\
assurance & \% of Total & $1.2 \%$ & $.0 \%$ & $1.2 \%$ \\
\hline Moderate & Count & 81 & 25 & 106 \\
assurance & \% of Total & $23.5 \%$ & $7.2 \%$ & $30.7 \%$ \\
\hline High & Count & 154 & 50 & 204 \\
assurance & \% of Total & $44.6 \%$ & $14.5 \%$ & $59.1 \%$ \\
\hline Very high & Count & 21 & 10 & 31 \\
assurance & \% of Total & $6.1 \%$ & $2.9 \%$ & $9.0 \%$ \\
\hline Total & Count & 260 & 85 & 345 \\
& \% of Total & $75.4 \%$ & $24.6 \%$ & $100.0 \%$ \\
\hline
\end{tabular}

Source: Compiled from the questionnaire

The relation between the gender of customers and their perception regarding assurance of bancassurance is not significant. This is because the Approx. Significant value of Cramer's V test is 0.504 , which is more than 0.05 ( $5 \%$ level of significance).

\subsubsection{Marital Status of Customers and Their Perception regarding Assurance of Bancassurance Channel}

The influence of the marital status of customers on their perception of assurance of bancassurance is given in Table 6 .

Table 6. Marital status of customers and their perception of assurance

\begin{tabular}{llccccc}
\hline & & \multicolumn{4}{c}{ Marital status } & \\
\cline { 3 - 6 } & & Married & Unmarried & Divorced & $\begin{array}{c}\text { Widow/ } \\
\text { widower }\end{array}$ & Total \\
\hline Low assurance & Count & 3 & 1 & 0 & 0 & 4 \\
& $\%$ of Total & $.9 \%$ & $.3 \%$ & $.0 \%$ & $.0 \%$ & $1.2 \%$ \\
\hline Moderate & Count & 95 & 5 & 1 & 5 & 106 \\
assurance & $\%$ of Total & $27.5 \%$ & $1.4 \%$ & $.3 \%$ & $1.4 \%$ & $30.7 \%$ \\
\hline High assurance & Count & 192 & 4 & 2 & 6 & 204 \\
& $\%$ of Total & $55.7 \%$ & $1.2 \%$ & $.6 \%$ & $1.7 \%$ & $59.1 \%$ \\
\hline Very high & Count & 29 & 2 & 0 & 0 & 31 \\
assurance & $\%$ of Total & $8.4 \%$ & $.6 \%$ & $.0 \%$ & $.0 \%$ & $9.0 \%$ \\
\hline Total & Count & 319 & 12 & 3 & 11 & 345 \\
& $\%$ of Total & $92.5 \%$ & $3.5 \%$ & $.9 \%$ & $3.2 \%$ & $100.0 \%$ \\
\hline
\end{tabular}


There is no significant correlation between the marital status of customers and their perception regarding assurance of bancassurance. This is because the Approx. Significant value of Cramer's V test is 0.312 , which is more than 0.05 ( $5 \%$ level of significance).

\subsubsection{Number of Family Members of Customers and Their Perception regarding Assurance of Bancassurance Channel}

The relation between the number of family members of customers and customers' perception of assurance of bancassurance is presented in Table 7.

Table 7. Number of family members of customers and customers' perception of assurance

\begin{tabular}{llcccccccccc}
\hline & & \multicolumn{1}{c}{ Family members } & & \multicolumn{2}{c}{ Total } \\
\cline { 2 - 12 } & & 8 & 1 & 2 & 3 & 4 & 5 & 6 & 7 & 8 & 8 \\
\hline \multirow{2}{*}{ Low } & Count & 0 & 0 & 0 & 2 & 0 & 1 & 0 & 1 & 0 & 4 \\
assurance & $\%$ of Total & $.0 \%$ & $.0 \%$ & $.0 \%$ & $.6 \%$ & $.0 \%$ & $.3 \%$ & $.0 \%$ & $.3 \%$ & $.0 \%$ & $1.2 \%$ \\
\hline Moderate & Count & 0 & 0 & 7 & 23 & 50 & 18 & 5 & 2 & 1 & 106 \\
assurance & $\%$ of Total & $.0 \%$ & $.0 \%$ & $2.0 \%$ & $6.7 \%$ & $14.5 \%$ & $5.2 \%$ & $1.4 \%$ & $.6 \%$ & $.3 \%$ & $30.7 \%$ \\
\hline High & Count & 1 & 2 & 14 & 45 & 95 & 31 & 14 & 2 & 0 & 204 \\
assurance & $\%$ of Total & $.3 \%$ & $.6 \%$ & $4.1 \%$ & $13.0 \%$ & $27.5 \%$ & $9.0 \%$ & $4.1 \%$ & $.6 \%$ & $.0 \%$ & $59.1 \%$ \\
\hline Very high & Count & 1 & 0 & 0 & 7 & 11 & 8 & 4 & 0 & 0 & 31 \\
assurance & $\%$ of Total & $.3 \%$ & $.0 \%$ & $.0 \%$ & $2.0 \%$ & $3.2 \%$ & $2.3 \%$ & $1.2 \%$ & $.0 \%$ & $.0 \%$ & $9.0 \%$ \\
\hline Total & Count & 2 & 2 & 21 & 77 & 156 & 58 & 23 & 5 & 1 & 345 \\
& $\%$ of Total & $.6 \%$ & $.6 \%$ & $6.1 \%$ & $22.3 \%$ & $45.2 \%$ & $16.8 \%$ & $6.7 \%$ & $1.4 \%$ & $.3 \%$ & $100.0 \%$ \\
\hline
\end{tabular}

The relation between the number of family members of customers and customers' perception regarding assurance is not significant. This is because the Approx. Significant value of Cramer's V test is 0.064 , which is more than 0.05 ( $5 \%$ level of significance).

\subsubsection{Family Income of Customers and Their Perception regarding Assurance of Bancassurance Channel}

The correlation between the family income of customers and their perception of assurance of bancassurance is outlined in Table 8 . 
Table 8. Family income of customers and their perception of assurance

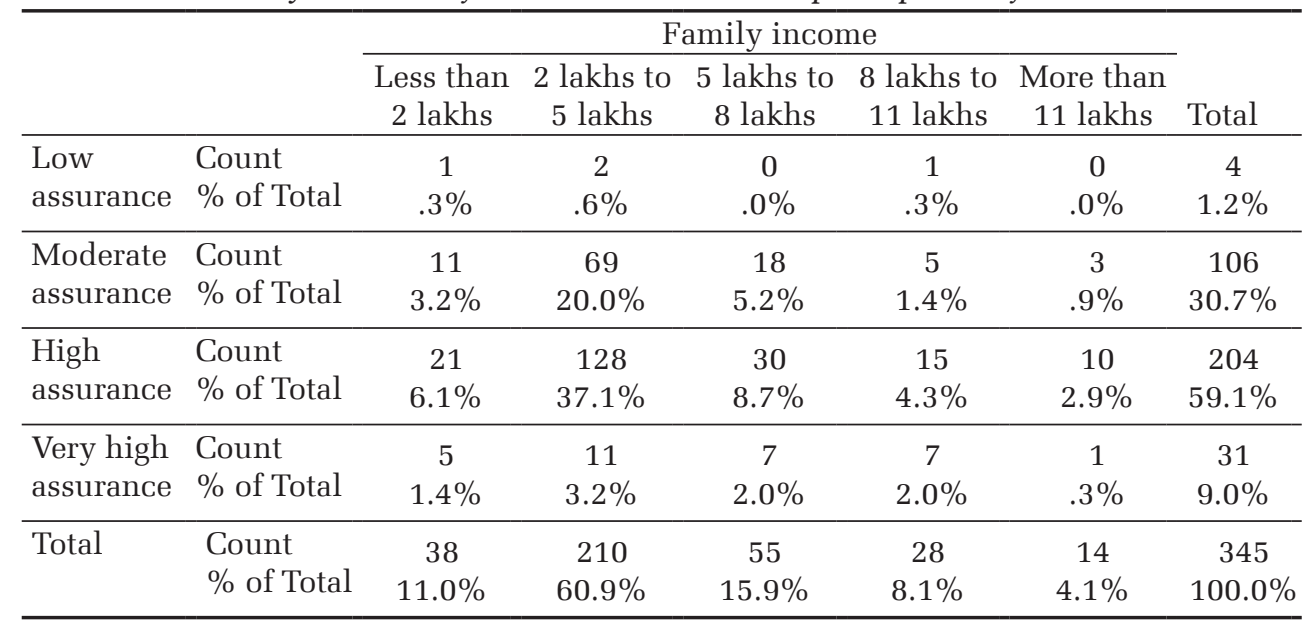

Source: Compiled from the questionnaire

There is no significant correlation between the family income of customers and their perception regarding assurance of bancassurance channel. This is because the Approx. Significant value of Cramer's V test is 0.085 , which is more than 0.05 ( $5 \%$ level of significance).

\subsubsection{Education of Customers and Their Perception regarding Assurance of Bancassurance Channel}

The relation between the education of customers and their perception of assurance of bancassurance channel is presented in Table 9.

Table 9. Education of customers and their perception of assurance

\begin{tabular}{llccccccc}
\hline & & \multicolumn{7}{c}{ Education } \\
\cline { 2 - 8 } & & $\begin{array}{c}\text { Less } \\
\text { than 10 } \\
\text { classes }\end{array}$ & $\begin{array}{c}\text { Less } \\
\text { than 12 } \\
\text { classes }\end{array}$ & $\begin{array}{c}\text { Under- } \\
\text { graduate }\end{array}$ & Graduate & $\begin{array}{c}\text { Post- } \\
\text { graduate }\end{array}$ & Other & Total \\
\hline Low & Count & 1 & 1 & 1 & 0 & 0 & 1 & 4 \\
assurance & $\%$ of Total & $.3 \%$ & $.3 \%$ & $.3 \%$ & $.0 \%$ & $.0 \%$ & $.3 \%$ & $1.2 \%$ \\
\hline Moderate & Count & 15 & 17 & 22 & 39 & 10 & 3 & 106 \\
assurance & $\%$ of Total & $4.3 \%$ & $4.9 \%$ & $6.4 \%$ & $11.3 \%$ & $2.9 \%$ & $.9 \%$ & $30.7 \%$ \\
\hline High & Count & 24 & 26 & 38 & 83 & 22 & 11 & 204 \\
assurance & $\%$ of Total & $7.0 \%$ & $7.5 \%$ & $11.0 \%$ & $24.1 \%$ & $6.4 \%$ & $3.2 \%$ & $59.1 \%$ \\
\hline
\end{tabular}




\begin{tabular}{llccccccc}
\hline & & \multicolumn{6}{c}{ Education } & \\
\cline { 3 - 8 } & & $\begin{array}{c}\text { Less } \\
\text { than 10 } \\
\text { classes }\end{array}$ & $\begin{array}{c}\text { Less } \\
\text { than 12 } \\
\text { classes }\end{array}$ & $\begin{array}{c}\text { Under- } \\
\text { graduate }\end{array}$ & Graduate & $\begin{array}{c}\text { Post- } \\
\text { graduate }\end{array}$ & Other & \\
\hline Very high & Count & 7 & 1 & 3 & 13 & 6 & 1 & 31 \\
assurance & $\%$ of Total & $2.0 \%$ & $.3 \%$ & $.9 \%$ & $3.8 \%$ & $1.7 \%$ & $.3 \%$ & $9.0 \%$ \\
\hline Total & Count & 47 & 45 & 64 & 135 & 38 & 16 & 345 \\
& $\%$ of Total & $13.6 \%$ & $13.0 \%$ & $18.6 \%$ & $39.1 \%$ & $11.0 \%$ & $4.6 \%$ & $100.0 \%$ \\
\hline
\end{tabular}

Source: Compiled from the questionnaire

There is no significant relation between the education of customers and their perception regarding assurance of bancassurance as the Approx. Significant value of Cramer's V test is 0.310, which is more than 0.05 ( $5 \%$ level of significance).

\subsubsection{Occupation of Customers and Their Perception regarding Assurance of Bancassurance Channel}

The correlation between the occupation of customers and their perception regarding assurance of bancassurance channel is presented in Table 10.

Table 10. Occupation of customers and their perception of assurance

\begin{tabular}{llccccc}
\hline & & \multicolumn{5}{c}{ Occupation } \\
\cline { 3 - 6 } & & Professional & $\begin{array}{c}\text { Employee } \\
\text { officer grade }\end{array}$ & $\begin{array}{c}\text { Employee non- } \\
\text { officer grade }\end{array}$ & Other & Total \\
\hline Low & Count & 0 & 1 & 3 & 0 & 4 \\
assurance & $\%$ of Total & $.0 \%$ & $.3 \%$ & $.9 \%$ & $.0 \%$ & $1.2 \%$ \\
\hline Moderate & Count & 2 & 17 & 87 & 0 & 106 \\
assurance & $\%$ of Total & $.6 \%$ & $4.9 \%$ & $25.2 \%$ & $.0 \%$ & $30.7 \%$ \\
\hline High & Count & 6 & 40 & 154 & 4 & 204 \\
assurance & $\%$ of Total & $1.7 \%$ & $11.6 \%$ & $44.6 \%$ & $1.2 \%$ & $59.1 \%$ \\
\hline Very high & Count & 3 & 3 & 24 & 1 & 31 \\
assurance & $\%$ of Total & $.9 \%$ & $.9 \%$ & $7.0 \%$ & $.3 \%$ & $9.0 \%$ \\
\hline \multirow{2}{*}{ Total } & Count & 11 & 61 & 268 & 5 & 345 \\
& $\%$ of Total & $3.2 \%$ & $17.7 \%$ & $77.7 \%$ & $1.4 \%$ & $100.0 \%$ \\
\hline
\end{tabular}

Source: Compiled from the questionnaire

The correlation between the occupation of customers and their perception regarding assurance is not significant. This is because the Approx. Significant value of Cramer's V test is 0.376 , which is more than 0.05 (5\% level of significance).

Thus, it can be concluded that there is no significant correlation between demographic variables and customers' perception regarding assurance of bancassurance channel. 
Multiple linear regression analysis is also performed to study the correlation between demographic variables and customers' perception regarding assurance of bancassurance channel. The result of the test is shown in tables 11 and 12 .

Table 11. Model summary

\begin{tabular}{ccccc}
\hline Model & $\mathbf{R}$ & R square & Adjusted R square & $\begin{array}{c}\text { Std. error of the } \\
\text { estimate }\end{array}$ \\
\hline 1 & $.257(\mathrm{a})$ & .066 & .008 & .61928 \\
\hline
\end{tabular}

From Table 11, it can be concluded that only $6.6 \%$ of the variance in customers' perception regarding assurance of bancassurance channel is accounted for by the independent variables.

Table 12. ANOVA $(b)$

\begin{tabular}{llrrrrr}
\hline Model & & Sum of squares & df & Mean square & F & Sig. \\
\hline 1 & Regression & 8.775 & 20 & .439 & 1.144 & $.303(\mathrm{a})$ \\
\hline & Residual & 124.256 & 324 & .384 & \\
\hline & Total & 133.032 & 344 & & \\
\hline \multicolumn{5}{c}{ Source: Compiled from the questionnaire }
\end{tabular}

Table 12 shows that ANOVA is not significant. This is because the value of significance for ANOVA is .303, which is more than .05.

Form tables 11 and 12, it can be concluded that since the value of $\mathrm{R}$ square is very low (.066) and the significant value for ANOVA is more than .05 there is no significant correlation between the demographic variables and customers' perception regarding assurance of bancassurance channel.

\section{Policy Implications and Conclusion}

The study found that customers perceive that the bancassurance channel has high assurance in case of procuring insurance-related services. This indicates that customers feel that the banks have provided enough safety and confidence in their insurance-related services. This finding is important because insurance represents a huge investment and customers evaluate highly those agents who are perceived to be trustworthy and make customers feel assured that they have made the correct decision. Insurance products are a very personal matter, where people desire the comfort of talking to experts who are knowledgeable on insurance (Loo, 2000). Moreover, the nature of the products is varied, making it difficult to judge the appropriateness of the products and creating a preference to talk 
to someone when a claim arises. Thus, customers' perception of bancassurance channel as having high assurance stands as a positive point for banks.

However, having confidence in banks has led most customers to take it for granted that there is no safety problem in dealing with any bank. This carelessness and recklessness of customers sometimes results in security breaches in Internet and phone banking. Thus, banks should make improvements towards eliminating the security concerns of the public. Banks should conduct extensive customer relations training programmes for all employees. Employees should be trained to remain motivated to perform their duty with the utmost care and with consideration to the concerns of the customers. Apart from this, utilization of technological advancements also plays an important role in improving the security measures of banking services and promoting the principle of confidentiality of information through information security systems.

For complicated products, such as insurance, employees must provide a clear explanation of each product to customers so that customers can feel confident about the services provided by banks.

The study also aims at finding out the influence of the demographic variables on customers' perception regarding assurance of bancassurance channel. It has been found that demographic variables have no significant influence on customers' perception regarding assurance. This is supported by both the Cramer V test and the multiple linear regression analysis. Therefore, it is irrelevant for the service providers to consider the demographic profile of customers in framing policies regarding customers' perception of assurance of bancassurance channel.

\section{References}

Aspfors, E. (2010). Customer perception of service, store image and product assortment: from an interior store perspective. Available at: http://www. theseus.fi/handle/10024/16719 (accessed: May 17, 2010).

Aggarwal, V. (2004). Bancassurance: concept, framework \& implementation. The Journal of Insurance Institute of India 30: 34-51.

Anderson, E. W.; Fornell, C.; Lehmann, D. R. (1994). Customer satisfaction, market share, and profitability: findings from Sweden. The Journal of Marketing 58(3): $53-66$.

Auka, D. O.; Bosire, J. N.; Matern, V. (2013). Perceived service quality and customer loyalty in retail banking in Kenya. British Journal of Marketing Studies 1(3): $32-61$.

Anjor, P.; Ali, S. H.; Kumar, M.; Verma, V. K. (2014). Service quality assessment: a study of consumer satisfaction in Indian insurance sector. IOSR Journal of Business and Management 16(3): 34-41. 
Blery, E.; Batistatos, N.; Papastratou, E.; Perifanos, I.; Remoundaki, G; Retsina, M. (2009). Service quality and customer retention in mobile telephony. Journal of Targeting, Measurement and Analysis for Marketing 17(1): 27-37.

Bitner, M. J. (1990). Evaluating service encounters: The effects of physical surroundings and employee responses. The Journal of Marketing 54(2): 69-82.

Culiberg, B.; Rojšek, I. (2010). Identifying service quality dimensions as antecedents to customer satisfaction in retail banking. Economic and Business Review 12(3): 151-166.

Choudhury, M.; Singh, R. (2015a). Customers’ perception regarding reliability of bancassurance channel: an empirical study. SIJ Transaction on Industrial, Financial and Business Management, 3(4): 41-48.

Choudhury, M.; Singh, R. (2015b). Perception of customers towards responsiveness of bancassurance channel: An empirical study in Assam. International Journal of Entrepreneurship \& Development Studies 3(1), 19-35.

Choudhury, M.; Singh, R. (2015c). Customer's experience in financial inclusion through bancassurance. The Journal of Insurance Institute of India 2(4): 55-61.

Choudhury, M.; Singh, R.; Saikia, H. (2016). Measuring customers' experience in bancassurance: an empirical study. Trziste 28(1): 47-62.

Dharmalingam; Senthil; Kannan. (2012). Assessing service quality dimensions of new private sector banks in Tamilnadu - An empirical study. Institute of Technology and Management 6(2): 1-14.

Ernest Yaw Tweneboah-Koduah; Augustine Yuty Duweh Farley. (2016). Relationship between customer satisfaction and customer loyalty in the retail banking sector of Ghana. International Journal of Business and Management 11(1): 249-262.

Hackl, P.; Scharitzer, D.; Zuba, R. (2000). Customer satisfaction in the Austrian food retail market. Total Quality Management 11(7): 999-1006.

Heryanto. (2011). Effects of service quality on customer satisfaction with Bank Nagari, main branch Padang. International Journal of Business and Management Tomorrow 1(2): 1-14.

Javadi, M. H. M.; Balochianzadeh, R.; Nasirzadeh, M. (2012). Gaps of service quality in private banks customers regarding SERVQUAL in Isfahan, Iran. Journal of Sociological Research 3(2): 68-83.

Khan, M. M.; Fasih, M. (2014). Impact of service quality on customer satisfaction and customer loyalty: evidence from banking sector. Pakistan Journal of Commerce and Social Sciences 8(2): 331-354.

Kaura, V. (2013). Antecedents of customer satisfaction: a study of Indian public and private sector banks. International Journal of Bank Marketing 31(3): 167-186.

Kheng, L. L.; Mohammad, O.; Ramayan, T.; Mosahab, R. (2010). The impact of service quality on customer loyalty: a study of banks in Penang, Malaysia. International Journal of Marketing Studies 2(2): 57-66. 
Koduah, E.; Farley, A. (2016). Relationship between customer satisfaction and customer loyalty in the retail banking sector of Ghana. International Journal of Business and Management 11(1): 249-262.

Kristensen, K.; Dahlgaard, J. J.; Kanji, G. K. (1992). On measurement of customer satisfaction. Total Quality Management 3(2): 123-128.

Lewis, B. R. (1993). Service quality: recent developments in financial services. International Journal of Bank Marketing 11(6): 19-25.

Lo Liang Kheng; Osman Mahamad; T. Ramayah; Rahim Mosahab. (2010). The impact of service quality on customer loyalty: a study of banks in Penang, Malaysia. International Journal of Marketing Studies 2(2): 57-66.

Lymperopoulos, C.; Chaniotakis, I. E.; Soureli, M. (2006). The importance of service quality in bank selection for mortgage loans. Managing Service Quality 16(4): 365-379.

Lymperopoulos, C.; Chaniotakis, I. E.; Soureli, M. (2006). The importance of service quality in bank selection for mortgage loans. Managing Service Quality: An International Journal 16(4): 365-379.

Lau, M.; Cheung, R.; Lam, A. Y. C.; Chu, Y. T. (2013). Measuring service quality in the banking industry: A Hong Kong based study. Contemporary management Research 9(3): 263-282.

Lo, L. K.; Osman, M.; Ramayah, T.; Rahim, M. (2010). The impact of service quality on customer loyalty: A study of banks in Penang, Malaysia. International Journal of Marketing Studies 2(2): 57-66.

Loo, F. (2000). Buying insurance on the net. Financial Planner February: 58-60.

Mengi, P. (2009). Customer satisfaction with service quality: An empirical study of public and private sector banks. Journal of Management Research 8(9): 7-17.

Malik, M. (2014). Bancassurance: boon to insurance development. American International Journal of Research in Humanities, Arts and Social Sciences 7(2): 155-159.

Munusamy, J.; Chelliah, S.; Hor Wai Mun (2010). Service quality delivery and its impact on customer satisfaction in the banking sector in Malaysia. International Journal of Innovation, Management and Technology 1(4): 398-404.

McColl-Kennedy, J.; Schneider, U. (2000). Measuring customer satisfaction: why, what and how. Total Quality Management 11(7): 1-14.

Malik Muhammad Eshan; Naeem Basharat; Arif Zoune. (2011). How do service quality perceptions contribute in satisfying banking customers? Interdisciplinary Journal of Contemporary Research in Business 3(8): 646-653. Muyeed, A. (2012). Customer perception on service quality in retail banking in developing countries - a case study. International Journal of Marketing Studies 4(1): 116-122. 
Nautiyal, G. (2014). Impact of service quality on customer satisfaction in the retail banking sector. Global Journal of Commerce and Management Perspective 3(3): 77-80.

Ndubisi, N. O. (2006). A structural equation modeling of the antecedents of relationship quality in the Malaysia banking sector. Journal of Financial Services Marketing 11(2): 131-141.

Ndubisi, N. O.; Wah, C. K. (2005). Factorial and discriminant analyses of the underpinnings of relationship marketing and customer satisfaction. International Journal of Bank Marketing 23(7): 542-557.

Nunnaly, J. (1978). Psychometric Theory. New York: McGraw-Hill.

Rajasekar, D.; Kumari, T. H. (2014). Bancassurance and its service quality dimensions: a study on customer attitude. International Journal of Applied Engineering Research 9(14): 2589-2600.

Selvakumar, J. (2015). Impact of service quality on customer satisfaction in public sector and private sector banks. Purushartha 8(1): 1-12.

Siddiqi K. O. (2011). Interrelations between service quality attributes, customer satisfaction and customer loyalty in the retail banking sector in Bangladesh. International Journal of Business and Management 6(3): 12-36.

Sharp, B.; Sharp, A. (1997). Loyalty programs and their impact on repeat-purchase loyalty patterns. International Journal of Research in Marketing 14(5): 473-486.

Saghier, N. E.; Demyana Nathan (2013). Service quality dimensions and customers' satisfactions of banks in Egypt. Proceedings of $20^{\text {th }}$ International Business Research Conference 4-5 April 2013, Dubai, UAE. 1-13.

Slattery, T. (1989). Special report: Nichols: we've forgotten the consumer. National Underwriter 48(November): 11.

Singh, J.; Kaur, G. (2011). Determinants of customer satisfaction: an empirical study of select Indian (universal) banks. Journal of Bank Management 10(1): $31-45$.

Siddiqui, M. H.; Sharma, T. G. (2010). Analyzing customer satisfaction with service quality in life insurance services. Journal of Targeting, Measurement and Analysis for Marketing 18: 221-238.

Singh, S., Sirohi, N. J.; Chaudhary, K. (2014). A study of customer perception towards service quality of life insurance companies in Delhi NCR Region. Global Journal of Management and Business Research: E Marketing 14(7): 20-32.

Santhiyavalli, S. (2011). Customers' perception of service quality of State Bank of India - A factor analysis. IJMBS 1(3): 78-84.

Sulieman, A. (2013). Basic dimensions of the SERVQUAL model and its impact on the level of customer satisfaction: an empirical study of the housing bank in Karak, Jordan. European Scientific Journal 9(1): 21-34. 
Venugopal, R. (2011). A viable additional channel - bancassurance. IRDA Journal 9(12): 33-37.

Vikas, G. (2011). Service quality perceptions of customers about insurance companies: an empirical study. Indian Journal of Marketing 41(3): 8-20.

Zeithaml, V. A.; Berry, L. L.; Parasuraman, A. (1996). The behavioural consequences of service quality. Journal of Marketing Management 60(April): 31-46.

Zeithaml, V. A.; Bitner, M. J. (2003). Service Marketing: Integrating Customer Focus across the Firm. New York: McGraw-Hill Higher Education. 